\title{
VALUATION OF THE ESCHERICHIA COLI AS A BACTERIAL POLLUTION INDICATOR IN THE FRESH MILK OF TIRANA (ALBANIA)
}

\author{
Vasilika Dini \\ Faculty of Veterinary Medicine, Agricultural University of Tirana, Albania \\ lika_dini@yahoo.com
}

\begin{abstract}
During 2004120 milk samples have been analyzed, which were taken from two different factories in Tirana (Albania). Out of these, 60 samples are unpasteurized milk, the other 60 samples are taken from the same milk, after the process of pasteurization. These samples have been analyzed for the presence of Escherichia coli as a bacterial contamination indicator, which can be dangerous for the consumers' health. The presence of Escherichia coli was identified in 4 cases out of which 3 were unpasteurized milk samples (5\% of unpasteurized milk samples or $2.5 \%$ of all samples). While 1 sample was part of pasteurized milk which represents $1.6 \%$ of pasterized milk samples or $0.8 \%$ of the total. The above results are real indicators for the presence of the bacterial contamination in unpasterized and pasteurized milk. It is evident that this study is a proof that indicates every deviation from pasteurization technology (represents a real risk for milk consumers when the binomial temperature time is not respected).
\end{abstract}

Key words: fresh milk; bacterial pollution indicator; Escherichia coli

\section{ПРОЦЕНУВАЊЕ НА ЕSСНЕRICНIА СОLI КАКО ИНДИКАТОР НА БАКТЕРИСКО ЗАГАДУВАЊЕ НА СВЕЖО МЛЕКО ВО ТИРАНА (АЛБАНИЈА)}

\begin{abstract}
Во текот на 2004 година беа анализирани 120 проби на млеко кои беа земени од две различни фабрики во Тирана (Албанија). Притоа 60 проби беа непастеризирано млеко, а останатите 60 проби беа земени од истото млеко по процесот на пастеризација. Пробите беа анализирани за присуство на Escherichia coli како индикатор на бактериска контаминација, што може да биде опасно за здравјето на потрошувачот. Присуството на : Escherichia coli беше потврдено во 4 случаи од кои 3 беа проби на непастеризирано млеко (5\% од пробите на непастеризирано млеко односно 2,5\% од сите проби), додека 1 проба беше дел од пастеризираното млеко, што претставува $1,6 \%$ од пробите на пастеризирано млеко, односно $0,8 \%$ од вкупната количина. Наведените резултати се реални индикатори кои ја докажуваат бактериската контаминација на непастеризирано и пастеризирано млеко. Очигледно е дека оваа студија е доказ кој укажува на отстапувања од технологијата на пастеризација (го прикажува реалниот ризик за консуматорите на млеко ако не се почитува температурата и времето на пастеризација).
\end{abstract}

Клучни зборови: свежо млеко; индикатор на бактериско загадување; Escherichia coli

\section{INTRODUCTION}

The quality of milk is determined by aspects of composition and hygiene. Due to its complex biochemical composition and high water activity milk serves as an excellent culture medium for the growth and multiplication of many kinds of microorganisms.

Therefore in the processing of milk, some of them may produce undesirable effects and some micro-organisms produce food infections which can either carry the pathogens that will increase the likelihood of infection of the consumer food. The sources of this contamination in fresh milk are numerous and are addressed to numerous factors such as animal hygiene, milking hygienic conditions, storage and transport care. A factor that makes the level of contamination worst is temperature (Nagle, 1999). High temperatures in the environment increase the number of microorgan- 
isms in a logarithmic scale/ml of milk (Fotadar, 2005). Furthermore milk can be contaminated indirectly from the mastitis manipulations of breast (Vasavada, 1987).

Milk is usually contaminated with different kinds of microorganisms at milk collecting places.

Among all micro-organisms Escherichia coli is a frequent contaminating organism, and is a reliable indicator of fecal pollution generally in sanitary conditions of water, food, milk and other dairy products (Hoeben, 2000).

Recovery of $E$. coli from food is an indication of possible presence of enteropathogenic and/or toxic microorganism which could constitute a public health hazard. Enteropathogenic E. coli (EEC) can cause severe diarrhea and vomiting in infants and young children

To improve the hygienic conditions in fresh milk it is necessary to carry out the process of pasteurization. Pasteurization is a thermal process used to decrease the contamination of microbes in milk. This is considered a safety method which guarantees destruction of all the vegetative forms of microorganisms (Bramley, 2000).

Considering the above facts the present study was designed to isolate the E. coli from milk in both pasteurized and unpasteurized samples.

\section{MATERIAL AND METHODS}

All the samples were collected in a sterilized container of $500 \mathrm{ml}$ in volume bottles, at random from two factories in Tirana and were brought to be analyzed at the Department of Microbiologic Control of Food in the Institute of Veterinary Research in Tirana.

All the samples positive for E. coli contamination was confirmed using 91/180/EEC0 which is a common method in the food microbiology lab.

During one year (2004) we tested 120 milk samples. Out of them 60 samples represented fresh milk and 60 samples of the same milk after the pasteurization process.

Each sample has its own evidence with some useful indexes such as milk quantity, sampling date, place of collection, transport condition.

For each sample the decimal solution from $10^{-1}$ up to $10^{-6}$ has been prepared The process has started with $25 \mathrm{ml}$ of milk and $225 \mathrm{ml}$ of diluted substance. The analytical process has taken into consideration that at the first dilution the number is extremely large.

Afterwards the procedure has been carried out acknowledging the other analytical indicators. The analytical procedure uses the standard methods ISO (ISO 11 866-2).

The valuation of the number of the coliforms and E. coli presence is realized by using the method with 3 rows, from 3 tubes of $9 \mathrm{ml}$ volume each one. At the first tube $1 \mathrm{ml}$ of each decimal dilution was sampled, so we arrived to take $10^{-1}$ $10^{-3}$ dilutions. Respectively each dilution was inoculated in one row with 3 Durham tubes (lactose bujon).

All the tubes were incubated in the temperature of $37{ }^{\circ} \mathrm{C}$ for $24-48$ hours. After the incubation, we investigated the gas presence in the Durham tubes. Positive cases were considered the tubes which demonstrated up to $1 / 3$ of the gas accumulation. $0.1 \mathrm{ml}$ of the microbe cultivation from the selected tubes were transferred in tubes with 9 $\mathrm{ml} \mathrm{BG} \mathrm{2 \%}$. The same procedure happened with them, they were incubated in the temperature of 42 ${ }^{\circ} \mathrm{C}$ for $24-48$ hours.

From all the positive reaction tubes after the incubation we took $0.1 \mathrm{ml}$ material and inoculated it in the tubes with $9 \mathrm{ml}$ tripton water of $1 \%$. With the last tubes we processed putting them in the incubator at $44{ }^{\circ} \mathrm{C}$ for 24 hours. At last the indol production (Kovac reagent) was confirmed which is considered a specific characteristic of the E. coli organism.

\section{RESULTS AND DISCUSSION}

The literature reviewed in the present study provided evidence that Escherichia coli is a frequent occurring organism in milk. Although E. coli is a frequent occurring organism in milk and its products, the incidence of the species of $E$. coli itself in milk and milk products as a possible cause of a food borne disease is insignificant because $E$. coli normally is a ubiquitous organism.

Important, however, is the occurrence of pathogenic strains of E. coli in milk products which could be hazardous for consumers. Thus, the results of the present study warn the need for more strict preventive measures. For this, regular sterilization of dairy equipment, washing of utensils, milker's hands, udders, eradication of diseased 
animals, pasteurization/boiling of milk is required before collection and distribution for consumption and product making. In this respect immediate cooling to $5{ }^{\circ} \mathrm{C}$ and/or pasteurization of milk could be more effective. The magnitude of the problem of bacterial contamination deserves more elaborative studies from the point of production of milk and milk products to the point of consumption and at all intermediary levels (Graph 1).

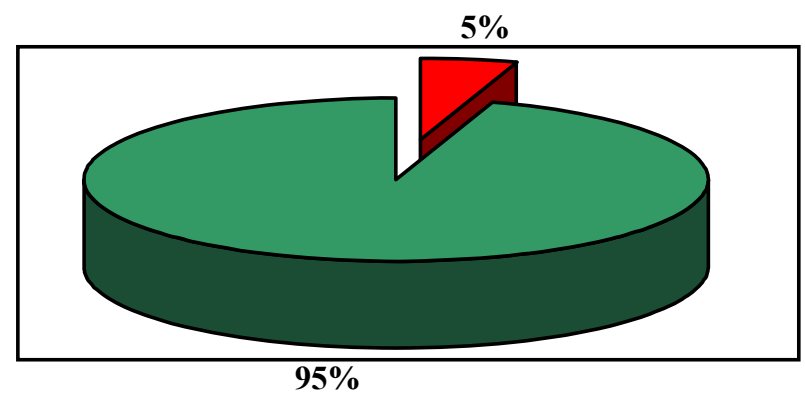

Graph. 1. The positive cases of $E$. coli identified in the samples of unpasteurized milk

$5 \%$ of the unpasteurized milk samples (60 samples) resulted positive for $E$. col presence

During 2004 we have analyzed 120 milk samples, which were taken from two different factories in Tirana (Albania). Out of these 60 samples are unpasteuized milk the other 60 samples are taken from the same milk after the pasteuization process. These samples have been analyzed for the presence of the Escherichia coli bacterial contamination indicator, which can be dangerous for the consumers' health. The presence of Escherichia coli was identified in 4 cases, out of which 3 were unpasteurized milk samples (5\% of unpasteurized milk samples or $2.5 \%$ of all samples). While 1 sample represented pasteurized milk or $1.6 \%$ of pasteurized milk samples in $0.8 \%$ of the total (Graphs 2 and 3).

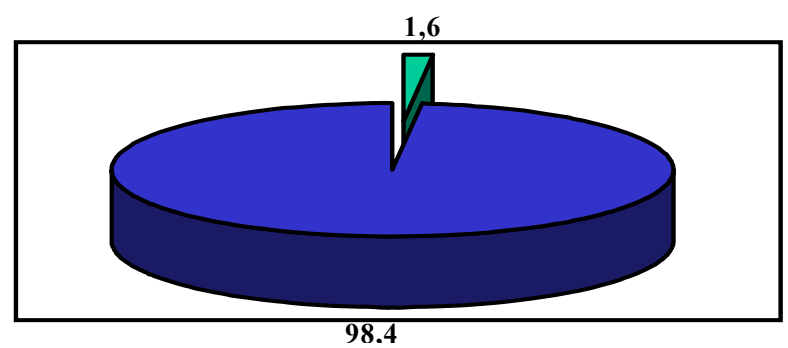

Graph 2. The positive cases of E. coli identified in the samples of pasteurized milk

$1.6 \%$ of the pasteurized milk samples (60 samples) resulted positive for E. coli

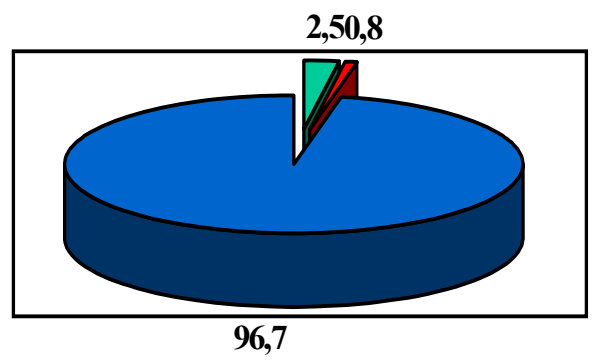

Graph. 3. The positive cases of $E$. coli identified in total of the samples of examined milk

$3.3 \%$ of the total of milk samples (120) have resulted positive with E. coli

The above results are real indicators that make in evidence the bacterial contamination in unpasterized and pasteurized milk. It is evident that this study is a proof that indicates every deviation from pasteurization technology (represents a real risk for milk consumers when the temperature is not respected - time binomial).

The presence of E. coli in the pasteurized milk indicates the extreme importance of regular pasteurization process. (Wang, 1997)

Table 1

Number of milk samples and their analytic indicators

\begin{tabular}{lcll}
\hline \hline Sort of sample & $\begin{array}{c}\text { No. of analyzed } \\
\text { samples }\end{array}$ & $\begin{array}{c}\text { Analytic } \\
\text { indicators }\end{array}$ & $=$ \\
\cline { 1 - 1 } $\begin{array}{l}\text { Unpasteurized milk } \\
\text { Pasteurized milk }\end{array}$ & 60 & Escherichia coli & etc. \\
\hline Total & 120 & \\
\hline \hline
\end{tabular}

Table 2

Positive cases with E. coli identified in the sampling milk

\begin{tabular}{ll}
\hline \hline Samples & Escherichia coli \\
\hline Unpasteurized milk & 3 samples \\
Pasteurized milk & 1 sample \\
\hline \hline
\end{tabular}

Table 3

Percentage of the positive cases and sort of samples

\begin{tabular}{lcccc}
\hline \hline $\begin{array}{l}\text { Analytic } \\
\text { indicator }\end{array}$ & $\begin{array}{c}\text { Nomer } \\
\text { of } \\
\text { positive } \\
\text { samples }\end{array}$ & $\begin{array}{c}\text { Percentage } \\
\text { of total of } \\
\text { samples }\end{array}$ & $\begin{array}{c}\text { Percentage of } \\
\text { total of } \\
\text { samples of } \\
\text { unpasteurized } \\
\text { milk }\end{array}$ & $\begin{array}{c}\text { Percentage } \\
\text { of total of } \\
\text { samples of }\end{array}$ \\
$\begin{array}{l}\text { pasteurized } \\
\text { milk }\end{array}$ \\
\hline coli & $4(3+1)$ & $3.3 \%$ & $5 \%$ & $1,6 \%$ \\
\hline \hline
\end{tabular}




\section{CONCLUSIONS}

Unpasteurized milk taken from tanks of two different factories in Tirana has resulted with bacterial contamination.

The unpasteurized milk has resulted with $E$. coli presence in $5 \%$, of the samples while the pasteurized milk in $1.6 \%$ of the samples

The presence of $E$. coli contamination is not due to the hottest periods of the year (spring-summer) because milk in these factories is collected and transported respecting the cooling chain.

Every deviation from pasteurization technology (when the binomial temperature time is not respected), represents a real risk for public health.

\section{REFERENCES}

[1] Alam M., Zurek L. (2004): Association of Escherichia coli 0157:H7 with houseflies on a cattle farm. Appl Environ Microbiol, 70 (12), 7578-7580.

[2] Alleberger F., Wagner M., Schweiger P., Rammer H. P., Resch A., Dierich M. P., Fried Rich A. W., Karch H. (2001): Escherichia coli 0157 infections and unpasteurised milk. Ped. Infect. Dis. J., 6 (10), 147-151.

[3] Becker A. L., Writer S. (2005): Alberta E. coli outbreak tied to milk shakes. Calgary Herald:11-13.

[4] Bielaszewska M., Janda J., Blahova K., Minarikova H., Jikova E., Karmali M. A. (1998): Human Escherichia coli 0157:H7 infection associated with the consumption of unpasteurized goat's milk. Epidemiol Infect. 119, 299305.

[5] Bosnić P. (2003): World production and quality of cow's milk. Mljekarstvo. 53, 1, 37-50.

[6] Bramley A. J., Dod F. H. (1984): Reviews of the progress of dairy science: Mastits control - progress and prospects. J. Dairy Res. 51-481.

[7] Centers for Disease Control and Prevention (1997): Standardized laboratory protocol for molecular subtyping of Escherichia coli 0157:H7 strains by pulsed field gel electrophoresis (PFGE). Atlanta: CDC,

[8] Christopher M. G., Prashakara V. C. (1997): Rapid and sensitive immunomagnetic separation-polymerase chain reaction method for the detection of Escherichia coli 0157 in raw milk and ice-cream. J. Dairy Res. 64, 87-93.

[9] Clemens J. D., Rao M. R., Chakraborty J., Yunus M., Ali M., Kay B., Van Loon F. P. L., Naficy A., Sack D. A. (1997): Breastfeeding and the Risk of Life-threatening Enterotoxigenic Escherichia coli Diarrhea in Bangladeshi Infants and Children. Pediatrics, 1, 100.

[10] Doyle Sean Dr., Daly P. Dr., Collier T. Dr. (2002): PCRELISA detection of Escherichia coli in milk. Letters in Applied Microbiology, 34, 222-226.
[11] Feng P., Weagant S., Grant M. (2002): Enumeration of Escherichia coli and the Coliform Bacteria. Bacteriological Analytical Manual (8th ed.). FDA/Center for Food Safety \& Applied Nutrition.

[12] Fotadar U., Zaveloff P., Terracio L. (2005): Growth of Escherichia coli at elevated temperatures. J. Basic Microbiol. 45 (5), 403-404.

[13] Greenfield R. A., Bruckmaier R. M. (2005): Gene expression of factors related to the immune reaction in response to intramamary Escherichia coli lipopolysaccharide challenge. J. Dairy Sci., 72, 120-124.

[14] Gillian V. H., Rennie M. D. S., Martyn D. K. (2002): Some food episodes from milk production, The Medical Journal of Australia, 177 (11/12), 614-618.

[15] Haeghebaert S., Le Querrec F., Gallay A., Bouvet P., Gomez M., Vaillant V. (2002): Les toxi-infections alimentaires collectives en France, en 1999 et 2000. Bull. Epidemiol. Hebdo. 23, 105-109.

[16] Hoeben D., Burvenich C., Trevisi E., Bertoni G., Hamann J., Bruckmaier R. M., Blum J. W. (2000): Role of endotoxin and TNF-alpha in the pathogenesis of experimentally induced coliform mastitis in periparturient cows. J. Dairy Res. 67 (4), 502-514.

[17] Kramer J., Cantoni C. (1991): Alimenti Microbiologia e Igiene, 2 Edicione Commision Decision of 14 February, 91/180/EEC Annex II, Chapter IV.

[18] Milk and Milk Products - General guidance for the preparation of test samples, initial suspensions and decimal dilution's for microbiological examination. ISO 8261:2001 (E), IDF 122 (2001) (E).

[19] Nagle N. E. (1999): Thoughts on today's food safety. Understanding product. Dairy, Food and Environmental Sanitation, 19 (8), 598-604.

[20] Neill M. A. (2000): Escherichia coli. In: Wilcox M. H, ed., Infection highlights 1999-2000. Oxford: Health Press, 38-46.

[21] Robert T. Marshall PhD (editor) (1992): Standard Methods for the Examination of Dairy Products, $16^{\text {th }}$ edition.

[22] Rupert M., Bruckmajer I. (2001): E. coli 0157 outbreak associated with the ingestion of unpasteurized goat's milk in British Columbia, Central Vancouver Island Health Region.

[23] Trevena W. B., Willshaw G. A., Cheasty T., Domingue G., Wray C. (1999): Transmission of Verocytotoxin producing Escherichia coli 0157 infection from farm animals to humans in Cornwall and west Devon. Community Disease and Public Health, 2 (4) 263-268.

[24] Tiecco G.; Microbiologia degli alimenti di origine animale.

[25] Vasavada P. C. (1987): Pathogenic bacteria in milk - A review. J. Dairy Science, 71, 2809-16.

[26] Wang G., Zhao T., Doyle M. P. (1997): Survival and growth of Escherichia coli 0157:H7 in unpasteurized and pasteurized milk. J. Food Protection. 60, 61. 